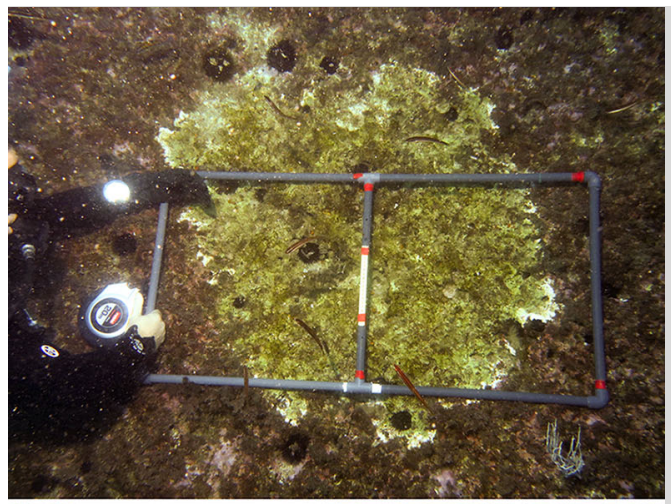

\title{
Diseases of coralline algae in the Mediterranean Sea
}
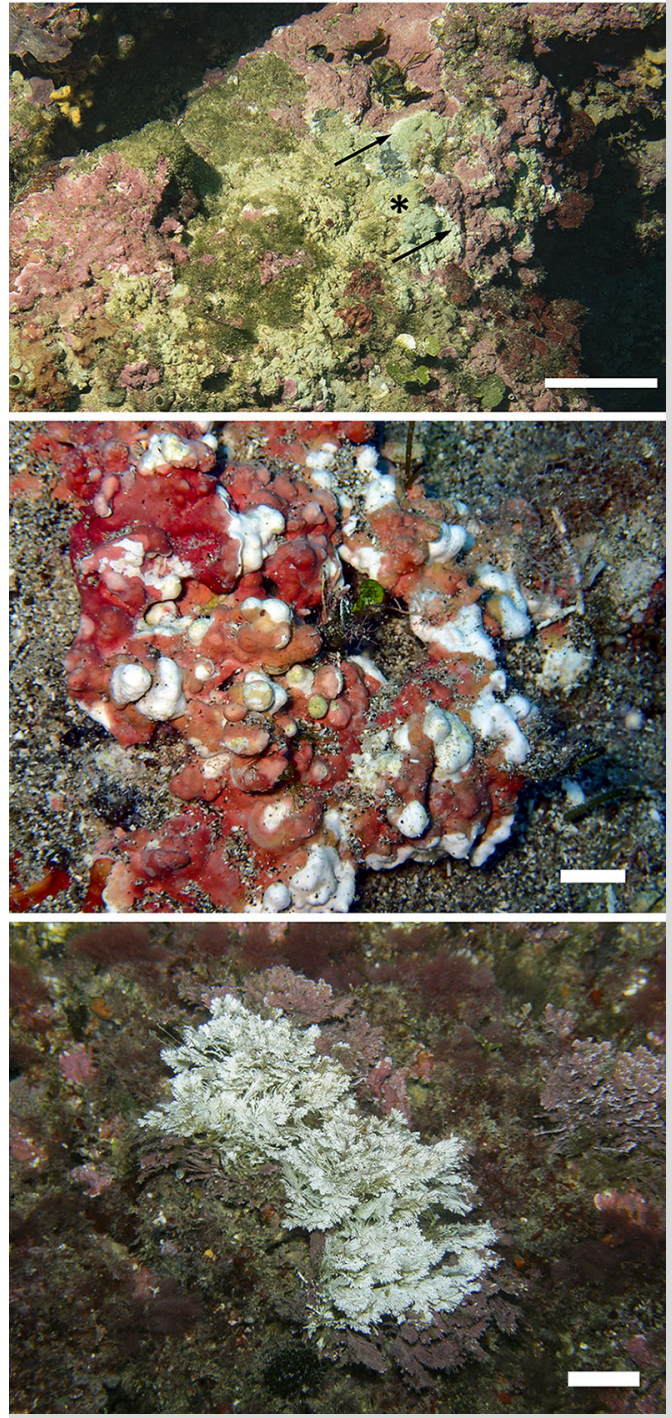

Fig. 1 Coralline algae affected by diseases. a Lithophyllum incrustans with coralline white band syndrome (CWBS) $(50 \times 1 \mathrm{~m}$ quadrat for scale). b Mesophyllum alternans with CWBS. Arrows indicate white band and asterisk shows green dead tissue. Scale bar $=10 \mathrm{~cm}$. c Neogoniolithon mamillosum and $\mathbf{d}$ Corallina elongata with coral white patch disease. Scale bar $=1 \mathrm{~cm}$
Diseases of coralline algae, first reported in the 1990s in the Pacific (Littler and Littler 1995), have recently been reported associated with high seawater temperature in several localities in the Caribbean (Quéré et al. 2015). Here, we report the first record of coralline algal diseases similar to the previously described coralline white band syndrome (CWBS) and coralline white patch disease (CWPD) in a temperate sea. In October 2015, after a summer characterized by positive thermal anomalies, we observed mortality affecting coralline algae at depths ranging from 0 to more than $30 \mathrm{~m}$ at three northwestern Mediterranean sites separated by hundreds of kilometers: Medes Islands $\left(42^{\circ} 03^{\prime} \mathrm{N}, 3^{\circ} 13^{\prime} \mathrm{E}\right)$, Cap de Creus $\left(42^{\circ} 19^{\prime} \mathrm{N}, 3^{\circ} 19^{\prime} \mathrm{E}\right)$, and Columbretes Islands $\left(39^{\circ} 53^{\prime} \mathrm{N}, 0^{\circ} 41^{\prime} \mathrm{E}\right)$. CWBS, characterized by a welldefined white band, affected crustose coralline algae, mainly Lithophyllum incrustans (Fig. 1a), Mesophyllum alternans (Fig. 1b), and Neogoniolithon mamillosum (Fig. 1c). The dead tissue associated with the disease appeared greenish, probably colonized by endophytic algae (Ballantine et al. 2005). The extent of injuries varied in diameter from several centimeters to about $1 \mathrm{~m}$. CWPD affected the same species, together with the geniculate coralline algae Corallina elongata (Fig. 1d), Jania rubens, and Amphiroa rigida at shallow depths. These species showed a diffuse white discoloration affecting the living algal tissue. In some cases, coralline algae had completely disappeared leaving bare rock areas. This process may have been enhanced by grazing by sea urchins. The emergence of thermo-dependent diseases may pose a new threat to Mediterranean coralligenous ecosystems in the context of global warming.

Acknowledgments We thank M. Marí, M. Pagès, P. Capdevila, E. Aspillaga, and J. Pascual for field assistance, and E. Ballesteros for his help in algal identification. We thank the Columbretes Islands Marine Reserve (MAGRAMA), the Medes Islands Marine Reserve, and Cap de Creus Natural Park (Generalitat de Catalunya) for their support.

\section{References}

Ballantine DL, Weil E, Ruiz H (2005) Coralline white band syndrome, a coralline algal affliction in the tropical Atlantic. Coral Reefs 24:117

Littler MM, Littler DS (1995) Impact of CLOD pathogen on Pacific coral reefs. Science 267:1356

Quéré G, Steneck RS, Nugues MM (2015) Spatiotemporal and species-specific patterns of diseases affecting crustose coralline algae in Curaçao. Coral Reefs 34:259-273

B. Hereu (iD $(\bowtie) \cdot$ D. K. Kersting

Departament d'Ecologia, Universitat de Barcelona, Diagonal 643, 08028 Barcelona, Spain

e-mail: hereu@ub.edu 